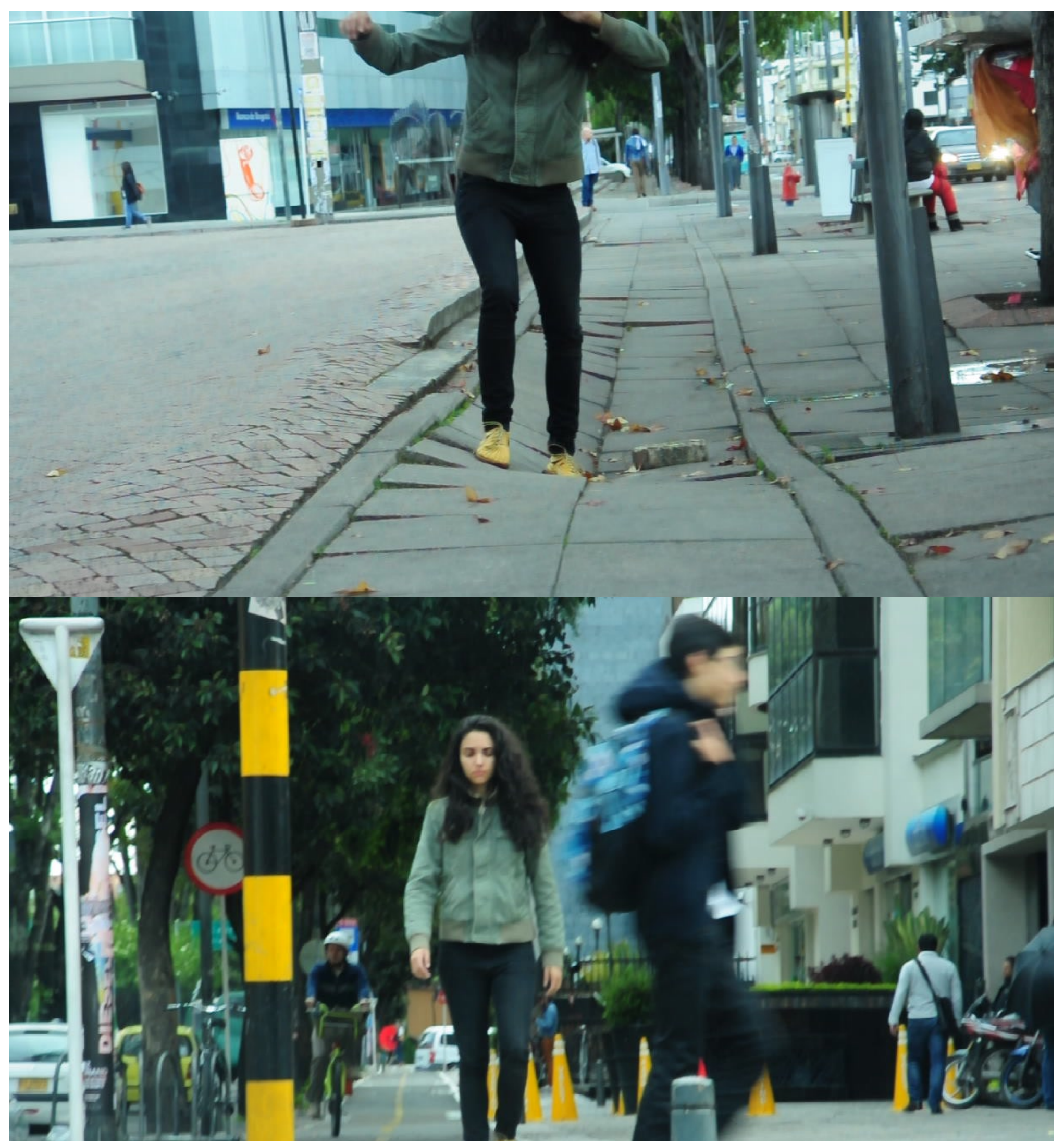




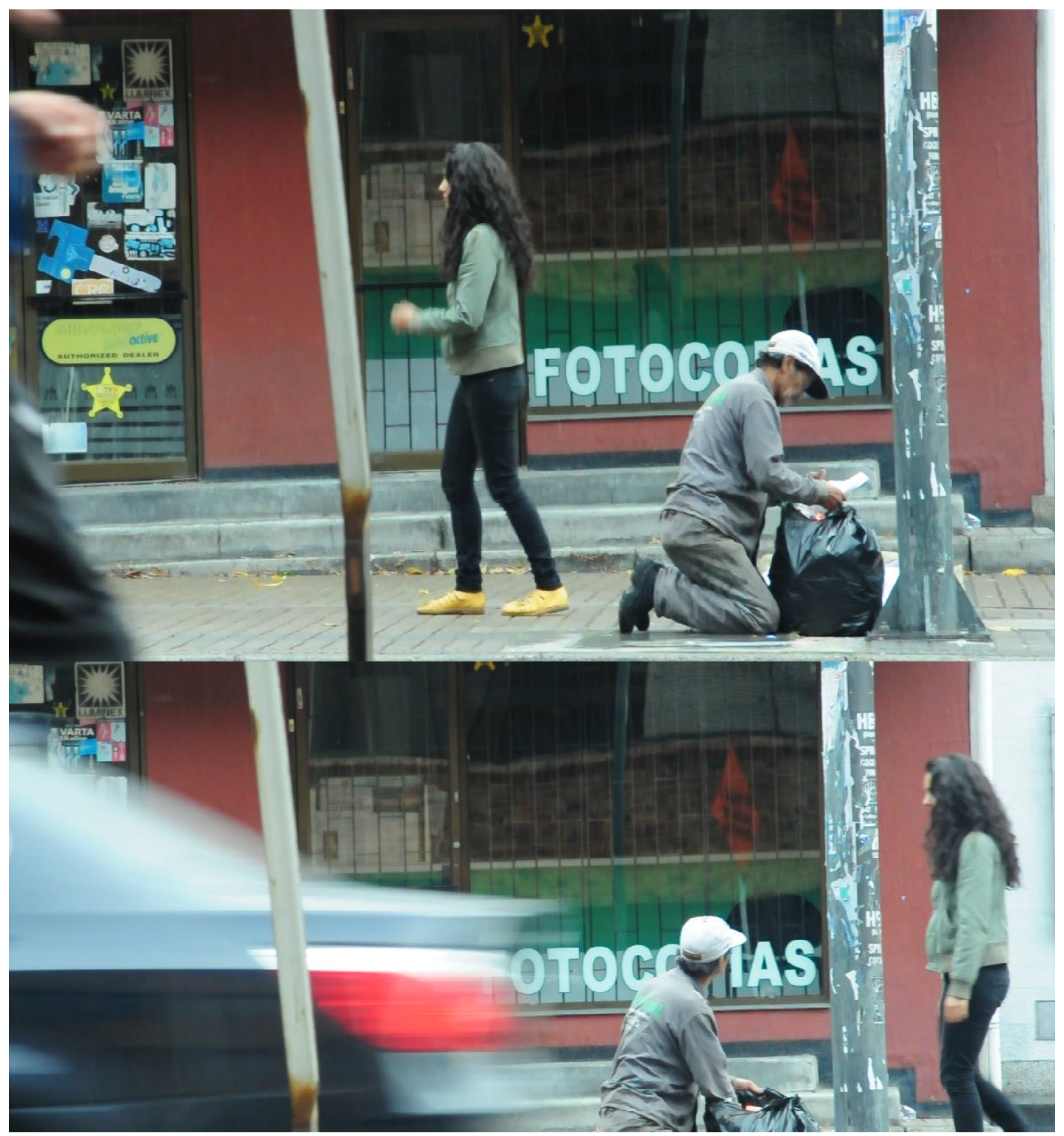


Ficha técnica

Título em português: Cartografias errantes do improvável agora Título em espanhol: Cartografias errantes de lo imprevisible Conceito: Maria Eugênia Matricardi Ação realizada por: Maria Eugênia Matricardi Tempo de duração: 4 dias Local: Lugares diversos em Bogotá, Colômbia Dispositivo: caminhar para trás Fotos: frames retirados do vídeo de David Ortiz Projeto: $6^{\circ}$ Encuentro de Acciones en Vivo y Diferido Câmera de vídeo: David Ortiz Produção: Tzitzi Barrantes, David Ortiz 


\section{cartografias errantes do improvável agora}

Maria Eugênia Matricardi

Andar de costas é a melhor forma de olhar de frente as coisas que estão atrás

(Des)caminhar. Exercício de cegueira. Agir dentro do não sabido arrastada pela falta de objetividade. Heterotopia nômade. Exercício de músculos, ossos, escuta, tato, irracionalidade, cenestesias não frequentadas comumente. Outros lugares de sensação. Cartografias errantes do improvável agora foi uma ação em que caminhei de costas durante quatro dias pelas ruas de Bogotá-Colômbia durante o $6^{\circ}$ Encuentro de Acciones en Vivo y Diferido. 
Parti de lugar algum. A proposta foi enviada ao evento por via da aleatoriedade: escolhi um ponto qualquer em Chapinero, um bairro de Bogotá, e nesta circunscrição um endereço desconhecido. Quase um jogo dadaísta. la partir de uma bodega chamada La finca de mi tío, que depois descartei para andar de costas em outro lugar qualquer. Qualquer lugar interessa.

A partir de um gesto simples, caminhar, sem utilizar nada mais que o próprio corpo como elemento da ação, abandonei a objetividade. Uma cidade que não conhecia, país estrangeiro, estrangeira eu no país. A cidade de ladrilhos, horizontes demarcados por montanhas, coturnos militares, fuzis, frutas na rua, música, baile de salsa, tecelaria indígena, sombrinhas atropelando cabeças correndo da chuva constante. Descobri medo por sombrinhas. Pontos de fuga: saída da estação: a pressa acotovela a lentidão andarilha. A lentidão pode ser um lugar de subversão em relação à organização social da pressa. Na calma atravessamos os instantes tranquilamente, reparando e escutando suas micropartículas: pastilha de aquarela se dissolvendo e colorindo a água, fermento do pão fazendo massa crescer, aroma de ervas perfumando o ar ao retirar o pires de cima da xícara de chá. A pressa amontoa circunstâncias, as coisas se tornam exterioridades a serem executadas. Sem muita profundidade faz-se mais, mas a qualidade dos afectos que circulam diminui.

Cidade grande, polimento urbano, nomes de igrejas e escolas militares por todas as partes. Gás lacrimogêneo no fim da tarde; correm os camelôs. Arepas de maíz com queso coajo, desvio do carrinho pelo cheiro e pelo calor da brasa. Um indígena vende pomada de maconha para as dores do mundo, mastiga folha de coca, organiza ervas, babosa. Andar de costas é a melhor forma de olhar de frente as coisas que estão atrás. Curupira andava de frente com os pés para trás traçando pegadas que desterritorializavam o espaço. Rastro ao contrário, pista que indica sempre o caminho errado. Caminho Curupira pelo erro. Nunca sabendo por onde piso. 
Uma moça pergunta:

- ¿Que estás haciendo?

- Experimentando otras formas de estar. Disse, e segui do avesso.

Não saber para onde ir coloca o corpo em risco, ao mesmo tempo em que o faz experimentar outros lugares de si e da cidade: a visão periférica se torna tão importante quanto à visão normal; menos foco, mais intuição, menos retina, menos doce, mais duro. Outros músculos do corpo são usados, mais costas, mais panturrilha. Muda o eixo de equilíbrio, pisar em falso muda a certeza. Quando caminhamos para frente nosso campo visual diminui, nos aproximamos do horizonte, a visão atua como zoom, recorte de imagem. Quando caminhamos de costas o horizonte se amplia e o campo visual aumenta. Mudanças sensíveis ocorrem.

Desvio: contra-dispositivo em relação ao fluxo corrente. A incisão parte de um gesto banal: (des)caminhar. Despropósito insistente, corpo inapropriado para produtividade. $\bigcirc$ tempo utilizado para o deslocamento aumenta, escorre lentamente, é mais fácil não saber, andar à deriva do que chegar a um ponto determinado. Arruína cumprir horários, chegar do ponto $A$ ao ponto $B$, o caminho vai pelo ponto cego. O tempo da utilidade é descapitalizado: maior esforço, mais tempo, menos eficiência. Andar, medo, deleite. Um buraco, paralelepípedo solto, desnível na calçada: qualquer obstáculo tomba. Cautela demanda tempo, previne atropelamento, insere lentidão nos gestos. Regime da lentidão x regime de produção de trabalho em escala capitalista, ainda que, paradoxalmente seja meu trabalho na produção de arte. Compõe mercado simbólico, decompõe mercado econômico: trabalho que (des)trabalha. 
Se o tempo do espairecimento se transformava cada vez mais em tempo de consumo passivo, o tempo livre tinha de ser um tempo dedicado ao jogo, tinha de ser um tempo não utilitarista, mas lúdico. Por isso, era urgente preparar uma revolução fundada no desejo: procurar no cotidiano os desejos latentes das pessoas, provocá-los, reativá-los e substituí-los por aqueles impostos pela cultura dominante. (CARERI, 2013, p.98)

Os situacionistas (JACQUES, 2012), em 1952, colocavam a cidade lúdica em detrimento da cidade útil, funcional, triturada pela passividade do consumo do tempo espetacular. Brincar para reinventar as próprias regras que diferem das regras de controle social, descobrir desejos singulares. Isso compreende guardar tempo para si, apaixonar-se pela vida por via do jogo, ter tempo de espairecimento que não fosse lazer de consumo passivo, nutrir certa repulsa ao trabalho assalariado e desfrutar da inutilidade do uso do tempo. Ter tempo livre, tempo vadio. Errância como guerrilha orientada pelo desejo.

Dice la policía:

- ¿Usted está contra todo el mundo? ¿Anda de espaldas mientras todo el mundo anda de frente?

Ele cuida da ordem das coisas, impede os desvios, regenera o padrão, pune erros, aplica a lei. Mas não há leis que consigam prever todas as possibilidades de erro. A diferença: absurdo não configurado como crime. Mudança de escala. Fora da circunscrição jurídica, desacertância, não ilegalidade. Um gago gagueja ou fala errado? Um gesto inútil, esforço pela leveza, suspensão do poder. Dispositivo de força bruta desarticulado, espaço liso espontâneo onde o controle não pode atuar. Habitar o espaço estriado a partir de uma lógica própria, tecendo alisamentos, fazendo uma reorganização sensível. Experimentar, lambuzar-se, mordiscar lugares possíveis dentro do vivido. 
Passasse de um mundo sensível a outro mundo sensível que define outras tolerâncias e intolerâncias, outras capacidades e incapacidades. O que está em funcionamento são dissociações: ruptura de uma relação entre sentido e sentido, entre um mundo visível, um modo de afeição, um regime de interpretação e um espaço de possibilidades; ruptura dos referenciais sensíveis que possibilitavam a cada um o seu lugar na ordem das coisas. (RANCIÈRE, 2012, p.66-67).

(Des)caminhar propõe ruptura na relação entre sentidos, atuando como diferença, agindo como dissenso. Gesto no comum que dissocia certo corpo de experiência cotidiana desmontando a economia policial das competências. Passa por inserir um espaço de impossibilidade no que seria o possível, redesenhando o que é visto, o que é fato, o que é sentido. Estética política que reinsere ficções no real promovendo fissuras subjetivas, obrigando-nos a perceber dados comuns de outras formas, cambiando nossos modos de afeição e interpretação do mundo. Compõe outras paisagens no corpo, na cidade, no mínimo que parte de si mesmo. Sustentar quase nada. Quase nada vagabundeia pelo espaço sem deixar marcas físicas. Sinais nomadizantes, não normatizantes (AQUINO \& MEDEIROS, 2011). Mondo al revés, flânerie às avessas. Sem pegadas, rastros ou grafias no espaço. Apenas registros, relatos, frames, imagens desfocadas em movimento, trepidações. Pura banalidade, distensão de sentidos, diferença de ritmo, outra cadência.

Vira-latas atravessam ruas despreocupados. A língua pende para o lado, goteja a baba. Estão sempre na iminência de serem atropelados, mas quase por apelo místico a sorte dos errantes os protegem. Buzina o carro, o cão segue no desvio, a pré-ocupação é do mundo, não dele, que se ocupa em farejar algum resto de comida para sustentar o movimento de suas patas. Presente constante. Nunca futuro. Talvez delírio. Delirium Ambulatorium¹ (ANJOS, 2012). Ambulatório: do latim, ambulatorius, que impele a andar. Andar delirante, sem destino, sem fim.

\footnotetext{
${ }^{1}$ Prática de vadiagem feita por Hélio Oiticica: andança, "delírio concreto" que se faz no encontro, confronto com as coisas comuns da cidade para gerar situações criativas.
} 
Assim como o cão que fareja contendo visão contemplativa imersa em distração, o corpo tateia o espaço atenciosamente distraído, disposto ao imprevisível.

deambular, perambular, perder-se, vagamundear, vagar sem rumo, ciganear, andar, andarilhar, flanar,( ) , vagabundear, zanzar, bestar, espairecer, estar à toa, vira-latear, reinventar-se.

"Deambulação, palavra que contém em si a essência da desorientação e do abandono ao inconsciente". (CARERI, 2013, p.82). Perder-se talvez seja uma das vias cognitivas que percorrem o encontrar-se. Entregar-se ao erro, deixar-se vulnerável, para o encontro, iterações com o mundo, dar-se margem para vazar o inconsciente. Abandono de certeza. Gosto pelo não sabido: Hélio Oiticica pegando ônibus de linhas desconhecidas indo até o ponto final para ver aonde dava. Lugares outros, somente isso, o que já desarma suficientemente a economia do tédio. Perder-se como experimentação de lugares, tatear a ignorância, seguir pelo faro, orelhas fitas. Aprender a aprender o espaço, mesmo que o (des)conhecido possa ter sido frequentado anteriormente. A questão passa por regenerar sua própria percepção, habitar o in.comum.

Se perder habita um lugar entre o desespero de não achar e um impulso delicioso por desbravar o desejo de encontro. Delirium ambulatorium, perambular como prática estética. O espaço é vivo, pulsante, autônomo, propõe relações, lugares, recortes de tempo, atemporalidades instantâneas, pessoas, cruzamentos, eventos; espaço sujeito em si mesmo.

No projeto Mitos Vadios, de 1978, de Ivald Granato, Hélio Oiticica decide caminhar, "poetizar o urbano", ambulatoriar: inventar o que fazer, recolher fragmentos de asfalto, colher o espaço, água do mar de Ipanema, punhado de terra do morro da mangueira; vadiagem inutilmente produtiva. 
A proposta do evento era em si uma experimentação do urbano, arruamento. Foi realizado em um terreno baldio, lugar entre um prédio e outro na Rua Augusta, São Paulo. Baldio e vadio rimam. A margem de um lugar desterritorializado, vazio simbólico em contraposição aos edifícios e lugares úteis preenchidos por estruturas, arquitetura, pessoas. Um terreno baldio pode ser um lugar que guarda as grandezas do ínfimo (BARROS, 2010), um lugar atemporal preservado das determinações simbólicas, dos significados da urbe. "Mitos vadios são mitos vazios" (OITICICA, 1978).

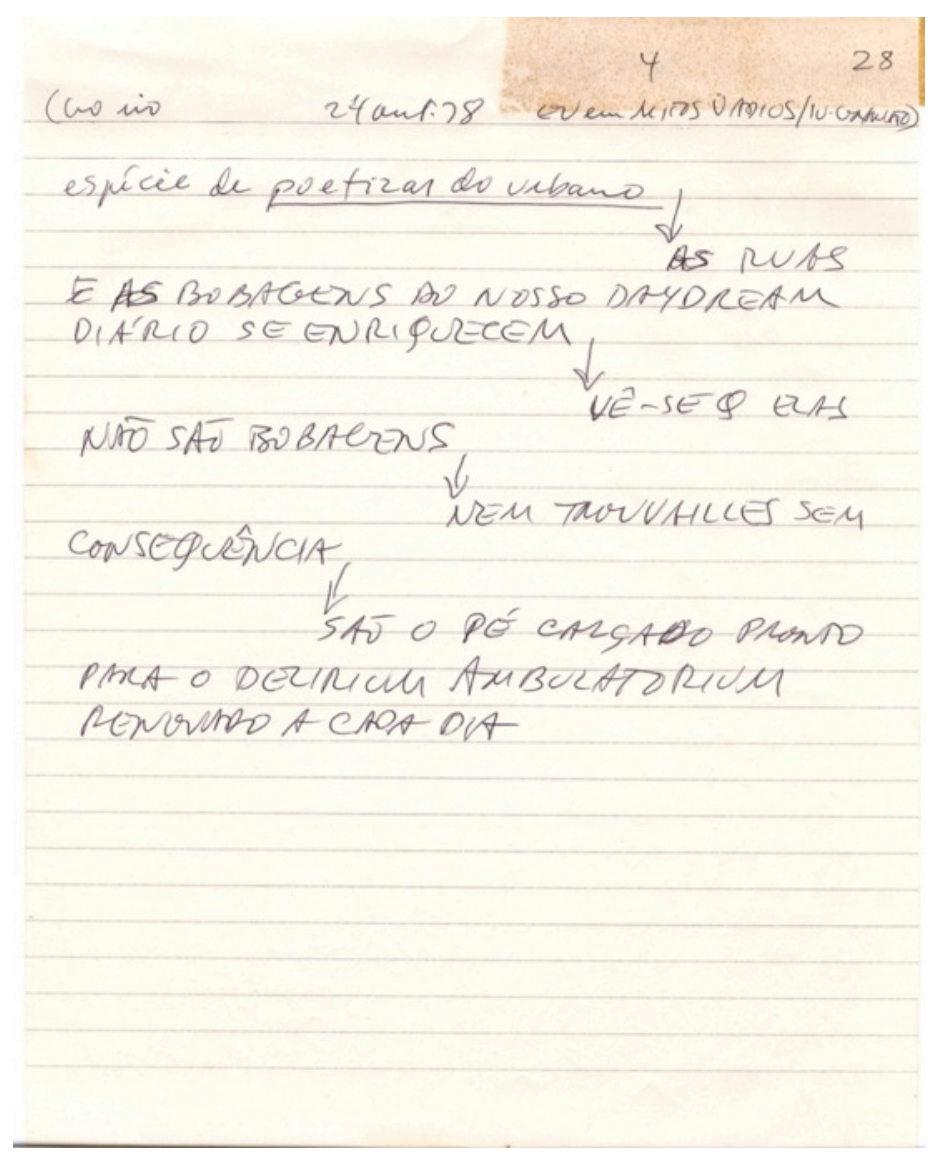

Rascunhos do texto de Hélio Oiticica sobre a participação em Mitos Vadios em São Paulo. 1978.

A flânerie de Charles Baudelaire, que ocorreu por volta de 1840 (2012, JACQUES), observava os movimentos efusivos da cidade em desenvolvimento urbano passando pela contemplação da mendicância; excedentes de gente despejados para fora do tecido social da urbs sem lugar definido. 
Moram em baixo do céu, se absorvem por multidões, ora para se perder, ora para se encontrar: anonimato e matilha ao mesmo tempo. Estrangeiro e cão como Diógenes, o cínico. Vivem o delírio da cidade, se embriagam de álcool, de paisagem, descobrem terrenos baldios, pequenas cavernas em baixo de viadutos. Caçam carteiras, abatem um otário, acendem fogueiras, inventam arquiteturas de papelão e placas publicitárias com sofisticação, tal qual na Rodoviária de Brasília, nas passagens subterrâneas fazendo becos infiltrados. O vagar nômade: busca de outros territórios, comida, água, talvez lixo, conhecimento de si, rituais de passagem/paisagem, amores, encontros com outros povos. Sempre ela, a viagem, a impregnar o corpo de vida. Pernas doloridas, sapato surrado, cabelo desgrenhado pelo vento. E ela sussurra no ouvido: tem coragem, segue em frente. Viagem esta com ou sem deslocamento geográfico. Viagem pelo lugar comum, cotidiano, cidade, bairro, corpo, outrados pelo revisitamento.

A aleatoriedade dadaísta (JACQUES, 2012) ao escolher a igreja Saint Julien le Pauvre em 1921 para fazer excursões a lugares que "não teriam nenhuma razão para existir" (des)vela a relação do caminhar como gesto estético, antiarte. Um lugar banal, cotidiano, cercado por um terreno baldio, sem representatividade histórica para Paris, sem eira nem beira. A potência da inutilidade toca o cotidiano, suspende as delimitações entre arte e não arte: regime estético. (RANCIĖRE, 2002). Espaço qualquer, algum lugar. Lugar possível, desvio no inconsciente da cidade, privilégio do abandono. (BARROS, 2010). 


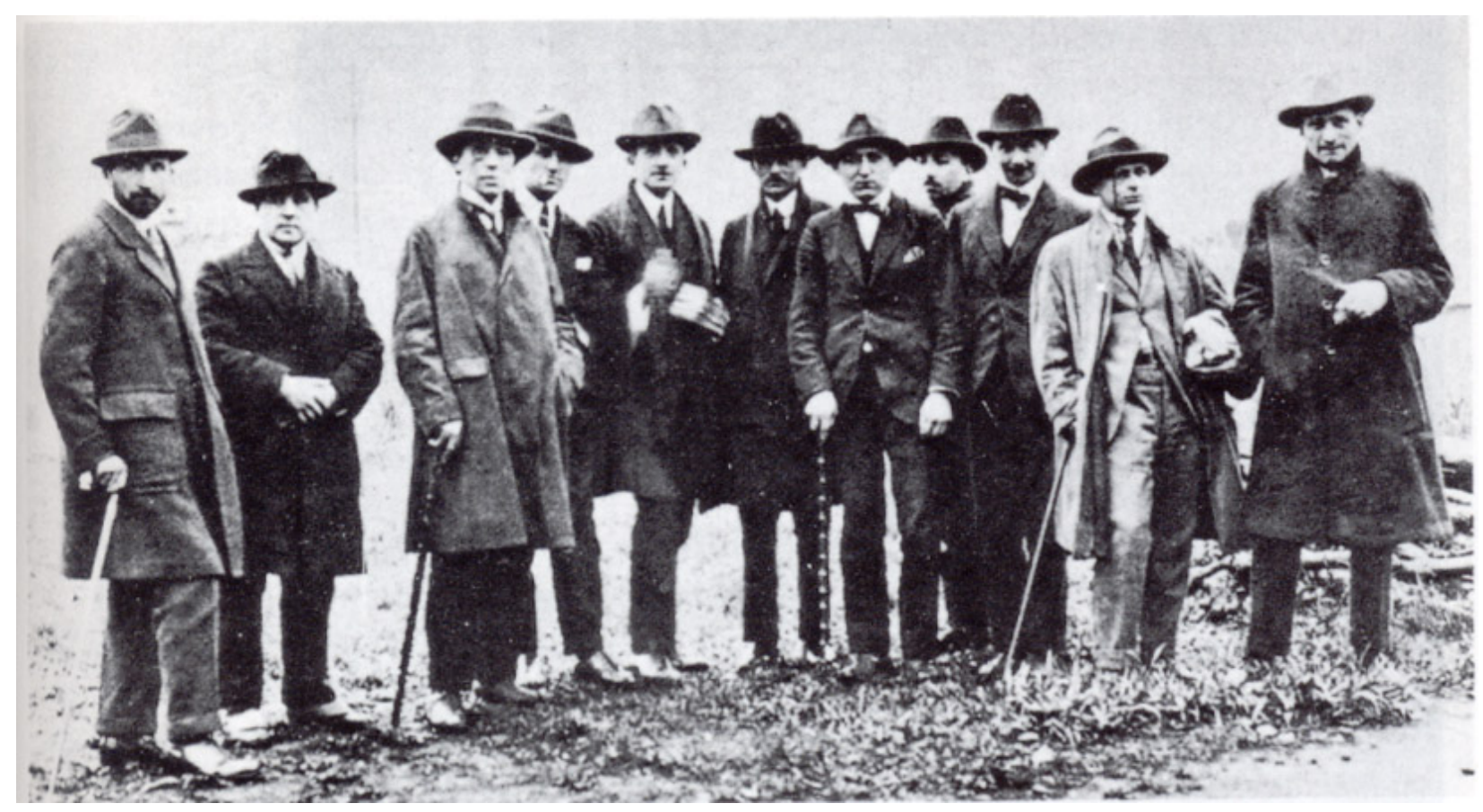

Deambulação dadaísta à igreja Saint Julien le Pauvre. 1921.

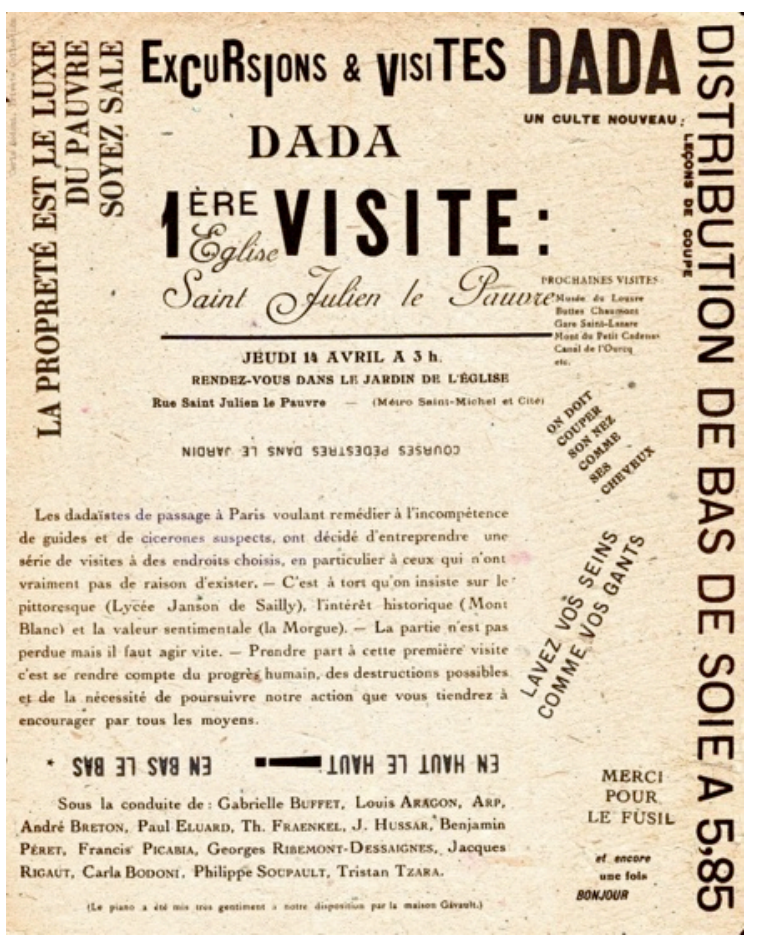

Panfleto da excursão dadaísta à igreja Saint Julien le Pauvre.1921. 
O panfleto distribuído pelos dadaístas, a divulgação nos jornais, o alarde, os registros, tecem a intencionalidade do gesto deslocando-o: o cotidiano é injetado de estesia. Essa transfiguração do lugar comum em possibilidade estética coloca em xeque a funcionalidade do território anterior, tornando a previsibilidade das importâncias desimportantes, enquanto outras articulações simbólicas e relações podem ser tecidas, transformando o lugar em um ready-made urbano sem objeto, reordenação simbólica do espaço. Esse movimento reconfigura o espaço desterritorializando-o, construindo outra realidade sensível. Assim como um objeto cotidiano, absolutamente comum, como um urinol ou um porta-garrafas passam a ser objetos de arte por deslocamento, um terreno baldio ou zona inóspita dos limites da cidade passam a ser habitados como lugar de possíveis, propícios a jogos e encontros singulares. Uma apropriação do banal. Anti turismo dadá.

Entre os bairros flutuantes encontrava-se o território vazio das amnésias urbanas. A unidade da cidade pode ser resultado exclusivamente da conexão de lembranças fragmentárias. A cidade é uma paisagem psíquica construída por meio de buracos, partes inteiras são esquecidas ou intencionalmente suprimidas para construírem infinitas cidades possíveis no vazio. (CARERI, 2013, p.9297).

Os surrealistas (JACQUES, 2012) buscavam no inconsciente estético das cidades, o estranho, o não familiar, do qual Sigmund Freud fala (Unheimilich). Estranhamento do lugar comum, uma perspectiva diferente da experimentação dadaísta, um apelo a uma intenção de encontro no in.comum, mais do que o exercício da aleatoriedade e elogio ao inútil. A cidade diz, sente, esquece, reverbera em seu corpo vibrátil lugares possíveis, sobreposições de camadas (des)veladas incessantemente. Há qualquer coisa de insuportável na cidade e, ao mesmo tempo, um desejo de habitá-la que exige a reexistência no mesmo. 
Tratar o espaço urbano como um grande corpo com impulsos próprios, atravessamentos, consciente e inconsciente foi herança surrealista. Os terrenos baldios, as periferias da cidade onde já não há mais interferência humana, as beiras de estradas, as periferias abandonadas pelo Estado, são lugares que dão margem ao encontro com este inconsciente. Lugares de encontros das margens.

Em 1970, Artur Barrio realiza a ação 4 dias e 4 noites² $^{2}$ em que deambula pelas ruas do Rio de Janeiro por 4 dias sem comer, até chegar a um limite de exaustão. O registro da ação se dá apenas por via de um breve relato, não há fotos ou vídeos. O tempo se torna matéria para ser modificada. O tempo histórico é aquele no qual incidimos com gestos, um rio no qual nadamos contra correnteza. A ação de Barrio pode ser o encontro radical do inconsciente da cidade com o corpo que deambula, andando exaustivamente, dormindo na sarjeta, com esgotamento físico e fome que transportam a consciência para o instinto e o delírio, sonho e realidade, excesso do real. Em Cartografias errantes do improvável agora, a diferença no meu corpo e no corpo da cidade não é produzida por esgotamento, mas pela re-existência dentro do próprio cotidiano para realizar tarefas comuns e manter rotina descapitalizada de tempo eficaz. A sutileza lúdica como dispositivo político, tendo o risco como aliado de mãos dadas.

Em 1931, Flávio de Carvalho faz a Experiência n² $2^{3}$, em que caminha em direção contrária a uma procissão de Corpus Christi com um chapéu na cabeça, o que se configura como uma afronta à multidão que correu atrás dele em tentativa de linchamento. Ele se refugiou em uma leiteria e depois foi resgatado da fúria odiosa dos crentes pela polícia. No relato dado à polícia que perguntou sua intenção ele respondeu que estava realizando uma "experiência sobre a psicologia das multidões" (CARVALHO apud JACQUES, 2004). Há caminhadas que dissolve o corpo na multidão, outras que a

\footnotetext{
${ }^{2}$ Disponível em: http://arturbarrio-trabalhos.blogspot.com.br/2008/10/realiza-o-trabalho-4-dias-4-noites.html ${ }^{3}$ Descrição da Experiência $n^{\circ} 2$ no catálogo $A$ cidade do Homem Nu. Museu de Arte contemporânea de São Paulo, 2010.
} 
enfrenta confrontando um corpo contra toda uma lógica social a custo de risco, produção de singularidade, política, desejo aventuroso por outridades.

Experiências caminhantes, nomadismo estético. O vagar nômade provoca deslimites sensíveis. O deslocamento geográfico ensina. É maravilhoso. No entanto, não precisamos percorrer geografias para estar em imersão ativa. Importa ter em si o sobrevôo do pensamento permeando territórios ilocalizáveis: deslocar-se subjetivamente produz diferenças no corpo. A paisagem e a arquitetura nos abraçam, sufocam, modulam. Os presídios, escolas e hospitais são asfixiantes não por acaso. A constrição do corpo é colocada a cada passo, seja física ou simbolicamente. Estar em um deserto, diante de um oceano, sentir a dignidade de uma montanha: a geografia do mundo inscreve seus sentidos na pele, habita nossos alvéolos, seja com fumaça fétida de automóveis, seja com ar puro do campo. Vertigem e atração por lançar-se ao precipício.

A deriva situacionista, dérive, adere outra camada política em seu projeto. Às práticas estéticas de experimentação da cidade, uma camada de sonho que não negava a realidade. São formas de heterotopias nômades que experimentam, vivenciam outros lugares, no mesmo lugar, produzindo diferença no corpo da cidade. As críticas ao trabalho assalariado, uso do tempo em seu "impulso lúdico" (SCHILLER, 1989), reorganização coletiva da cultura, algo que pudesse constituir outras formas de vida. A arquitetura, entendida como forma direta de organizar o tempo, o espaço e os afectos, foi assim, questionada como forma de controle.

O adjetivo psicogeográfico, que conserva uma incerteza bastante agradável, pode então ser aplicado às descobertas feitas por esse tipo de investigação, aos resultados de sua influência sobre os sentimentos humanos, e inclusive de maneira geral a toda situação ou conduta que pareça revelar o mesmo espírito de descobrimento. (DEBORD apud FELíCIO, 2007, p.36). 
A psicogeografia situacionista não se deteve apenas nos delírios do inconsciente da cidade, era preciso respirar fundo, sonhar sim, mas perceber conscientemente a atuação do espaço sobre os indivíduos e suas relações de poder. Urbanismo e arquitetura não se referem apenas a espaços físicos que compõem a geografia, mas espaços de poder onde a cidade exala seus devires, suas intenções. O encontro com bairros, ruas, edifícios, era percebido como componente subjetivo, que não estava relacionado diretamente com as intenções funcionais de construção desses espaços. Para tecerem tais observações os situacionistas utilizavam métodos não acadêmicos, que demarcavam algumas intencionalidades de acordo com as circunstâncias, sendo, portanto, inclinado à poesia.

A arquitetura, como nas culturas nômades, torna-se um percurso, espaço de ir, conexão de lugares onde o sedentarismo não encontra razão para alojar-se. Os situacionistas falavam de uma arquitetura dinâmica, móvel, permeável às possibilidades de outras construções de modos de vida. Essa vontade de lugares possíveis também se dava na forma de jogos com deliberação de algumas proposições, deriva e experimentação da cidade como reinvenção da própria vida, questionamento da funcionalidade da cidade dentro de uma economia espetacular submissa ao sistema de produção capitalista e economia do tédio, que busca fixar as formas como lugar ideal não suscetível à impermanência das formas e desejos. Percebiam o espaço como relação, por ser ele sujeito sensível com seus fluxos e passionalidades. Pensavam na cidade com zonas sombrias, afetivas, com atmosferas psíquicas cambiantes.

O situacionista Constant Nieuwenhuys pensou o urbanismo em escala mundial no projeto utópico New Babylon. Uma cidade inspirada em acampamentos ciganos onde os espaços vazios e os lugares de encontros labirínticos uniam o trânsito de pessoas, podendo iteragir com a hibridização da cultura e as fronteiras estabelecidas pelo controle territorial e políticas de Estado que se dissolveriam na desterritorialização destes lugares. 
No projeto, a arquitetura é suspensa por palafitas gigantes, onde o espaço vazio dos terrenos ficaria disponível para a invenção de espaços lúdicos e plantio de área verde. A precariedade dá origem a um projeto sofisticado. Delírio e nomadismo desconstroem por via da arquitetura a lógica sedentária paralisante. Movimento contido na fixidez.

Os projetos situacionistas de cidades experimentais e a New Babylon de Constant não chegaram a ser materializados por limitações econômicas, e obviamente políticas. Quem financiaria perigosos delírios lúcidos? Tais ideias colocavam em risco modos de produções de vidas questionando os códigos simbólicos que produzem e fazem a manutenção do capitalismo cultural. A perspectiva passa justamente por isso: construção de outras realidades sensíveis. As representações simbólicas do espaço influenciam diretamente no sujeito que o habita. A desterritorialização precisa ser feita no próprio território, torcendo, implodindo, construindo outras possibilidades de vida, de liberdade, de arte, de arquitetura, de fluxo, de paisagens sensíveis, de inusitado. Deslimites.

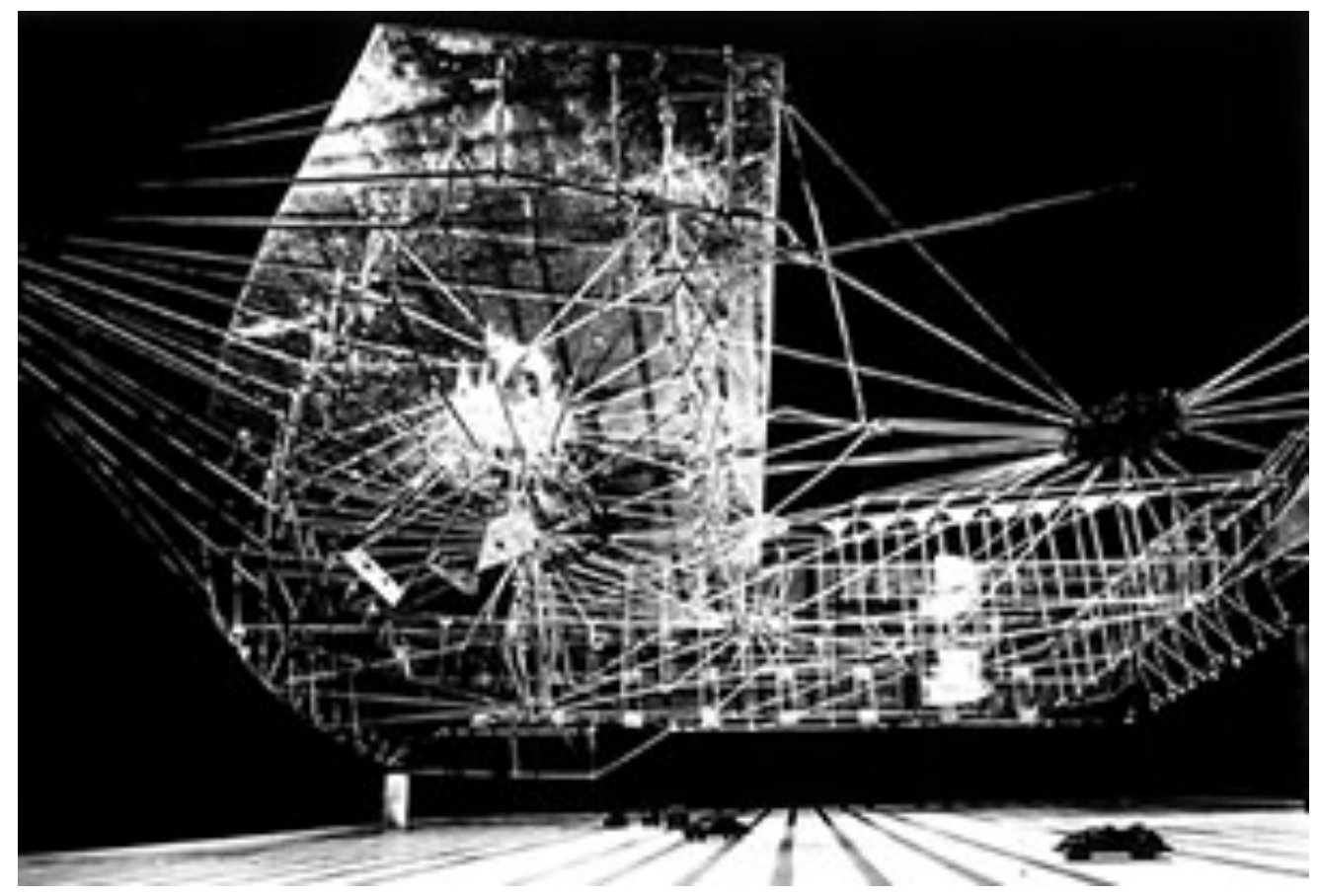

Projeto de New Babylon. Constant Nieuwenhuys. 1969. 


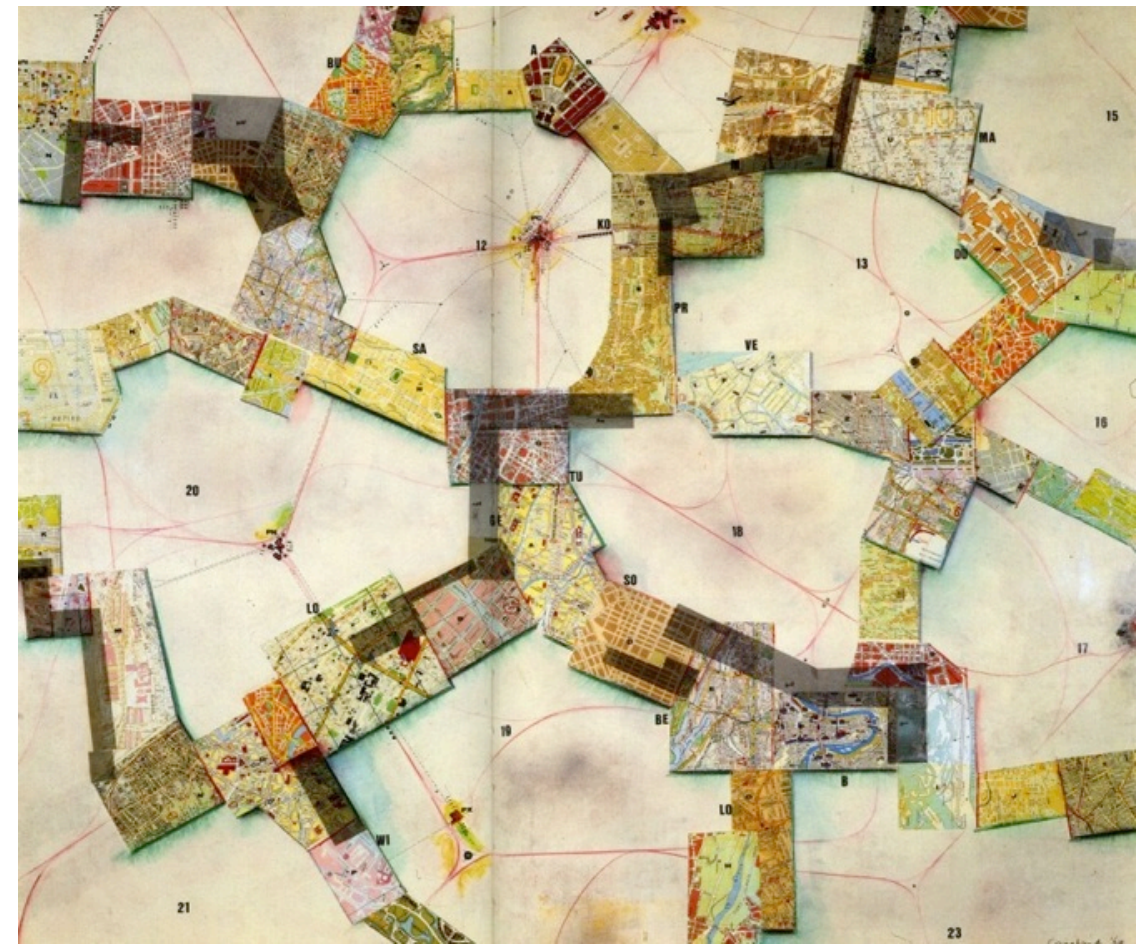

Representação simbólica de New Babylon. Colagem. Constant Nieuwenhuys. 1969.

Os fluxos psicogeográficos, a deriva, as deambulações e delírios consistentes evocam a impermanência, o que há de orgânico nas formas. Como nuvens os passos mudam, caminham, se deslocam, buscam zonas de condensação afetiva, catalisam energias de átomos em movimento que eletrificam os encontros tempestuosos, fazem chover, trovejar. Sopram o que há de vento nos passos. O corpo vento se expande, ocupa quinas, percebe as coisas enquanto é percebido por elas.

A história do caminhar é estética. As migrações povoaram o mundo. O ser não civilizado rabiscava, a cada passo, uma parede de caverna. Aglomerava pedras, menires, resignificava simbolicamente, magicamente os lugares percorridos. A arte, não somente contemporânea, tem diálogo direto com o simples ato de caminhar: escuta do espaço; mobilizando, pulsando vida em detrimento de forças imobilizadoras. 


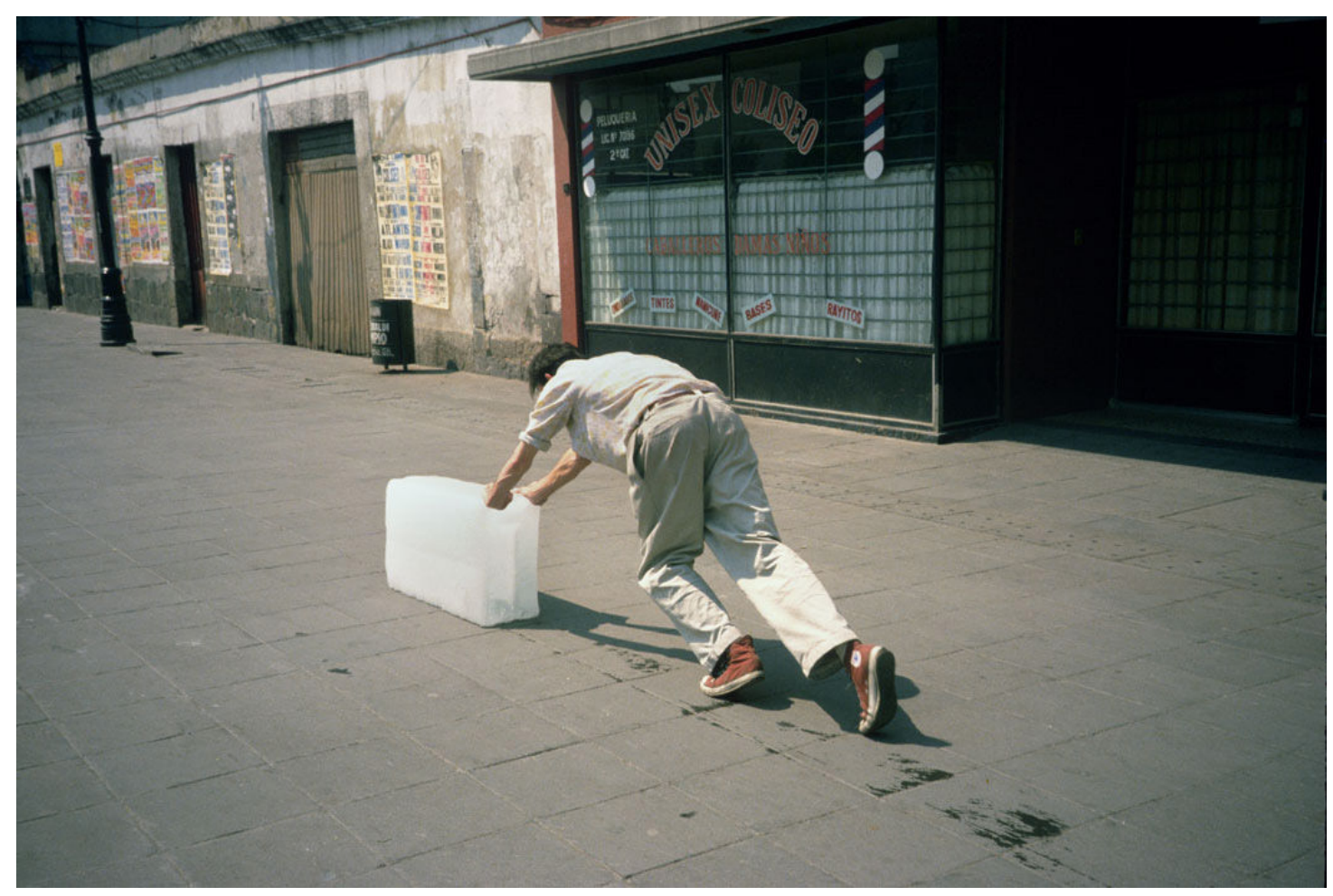

Paradoxo (às vezes fazer algo pode levar a nada). Francis Alÿs. Ação na Cidade do México. 1997.

São os passos de Francis Alÿs empurrando um bloco de gelo na Cidade do México na ação Paradoxo (às vezes fazer algo pode levar a nada) de 1997. Re-existir no mesmo gerando absurdos. O caminhar de Alÿs traz outra vibratilidade para o corpo da cidade: reinsere inusitado na economia do tédio. Fazer que não faz nada. Nada potencializa inutilidade, política estética. Instaura heterotopia nômade, efêmera, que se dilui a cada gota do gelo que escorre pelo concreto quente. Quase nada portador de incógnitas, possibilidades de desvios desobjetivantes. Percurso que não determina, não qualifica: alargamento de regime sensível, com fim em si mesmo. Aqui a água é gelo, mas dura como a da mangueira que jorra lavando os contornos do previsível. Jorrar é gotejar na afecção do derretimento, da utilidade imprópria, liquefazendo-se vulnerável, como meu corpo após 20 minutos em jorro-fluxo: derretimento de si, exausto e sem órgãos. Alÿs propõe outros derretimentos, delicados em gesto, vibrando em frequências dissonantes dos ruídos da cidade. 


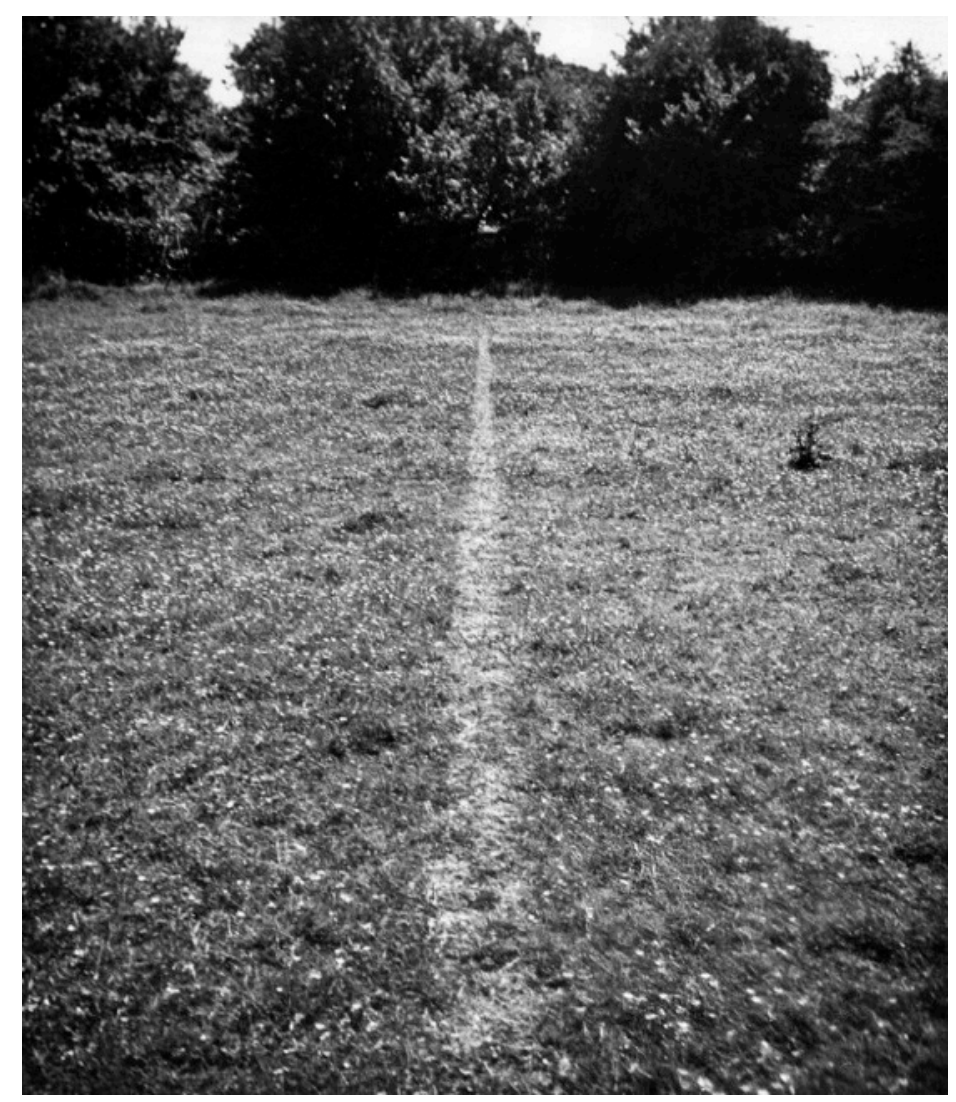

A line made by walking. Ação. Richard Long. 1967.

Richard Long pisa na grama para traçar uma linha na paisagem em A line made by walking $^{4}$, de 1967. Diferente da força intervencionista de outras práticas da Land Art, que ferem paisagem, movem montanhas de terra, escavam pedras utilizando maquinário pesado, mobilizando forças do progresso, domesticação humana da geografia, Long constrói suas heterotopias nômades a partir da delicadeza. De forma simples, apenas com seu corpo, ele escuta a paisagem. Compõe junto, sem feri-la. Passos na grama que desterritorializam o espaço, espaço que se re-territorializa ao crescer da grama. Importa o processo, sutil percurso. A linha no chão traça um mapa subjetivo no espaço. Mapa que não determina como os mapas da política do Estado, delimitando fronteiras políticas e econômicas. Seria mais uma cartografia nômade que se faz no encontro, como afecto e se dissolve no tempo, sem definir, sem obrigar.

\footnotetext{
${ }^{4}$ http://www.richardlong.org
} 
Nos diálogos diaspóricos, Notícias da América de Paulo Nazareth5 ${ }^{5}$ de 2011, a ação aborda políticas de migração, mestiçagem, nomadismo, encontros e percursos que acumulam a poeira nos pés de todos os lugares pelos quais passou, desde Minas Gerais até o Brooklyn nos Estados Unidos.

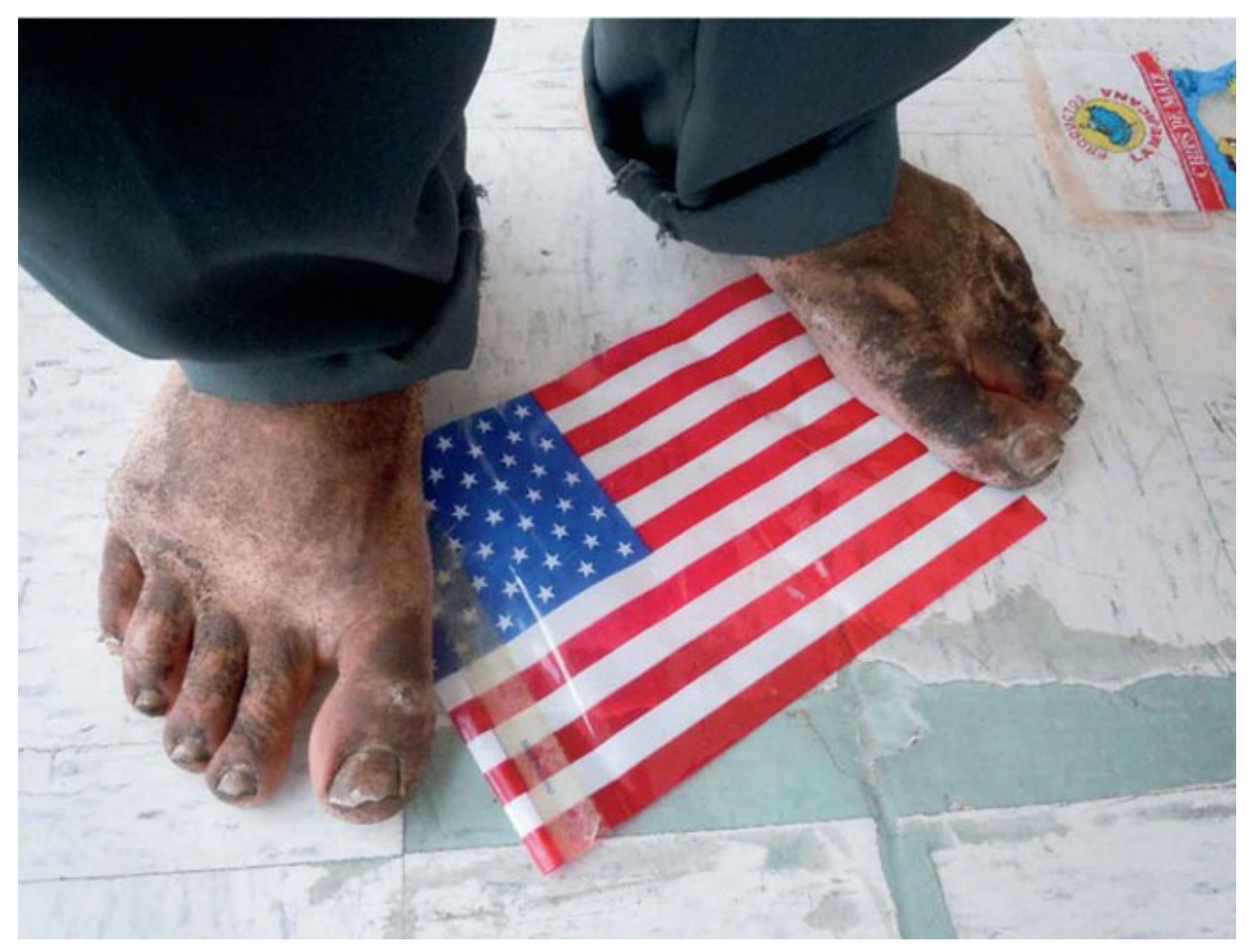

Notícias da América. Ação de Minas Gerais ao Broocklyn E.U.A. Paulo Nazareth. 2011.

$\mathrm{Na}$ viagem, como processo, ele fez escambo afetivo, catira [sic]: troca de produtos, coisas, nem sempre condizentes com seu valor de custo, mas por seu valor afetivo. Recados levados a desconhecidos, questões políticas riscadas em papelão ordinário: placa de carona para viagem geográfica e subjetiva. Vagabundo de patas rachadas, como dizem no México os indígenas que não tinham la plata para comprar sapatos. Pés sujos de poeira, rachados de mundo, abriendo grietas pelas fronteiras, pelo direito à paisagem.

\footnotetext{
${ }^{5}$ http://latinamericanotice.blogspot.com.br/
} 
Os pés caminham tingindo-se de espaço, construindo para si outramentos, outra pele. Sola do pé no couro do mundo, redimensionando regimes sensíveis, diluídos como fronteiras, reconhecidos na fisionomia de negros, negras, indígenas, micropolíticas e genocídio de ditaduras. São passos.

Cartografias errantes do improvável agora é devir curupira no (des)caminhar. Andar ao contrário dos próprios sentidos, habitar o inusual de si. Transpirar espaço. Inspira-lo ao contrário, ativar o desconhecido que mobiliza, movimenta. O corpo, apenas. Partir do mínimo. Insistir em delirium ambulatorium, produzindo heterotopia nômade, particularidade de um modo de vida experimentado naquele entre-tempo. Desvio ativo que incomoda a ordem, desperta risos, franze cenhos, tropeça em carrinhos de picolé, tomba em paralelepípedos, anda lento em escolha por outra musicalidade dos próprios gestos que fogem à partitura social. Esta ação produz diferença, política. Andar antifuncional, degustando a inconsciência do ato de caminhar, despertando no corpo outra qualidade de atenção. No fim caminhamos sempre sem saber aonde vai dar.

\section{referências}

BARROS, Manoel. Poesia completa. São Paulo: Leya, 2010.

CARERI, Francesco. Walkscapes: o caminhar como prática estética. São Paulo: Editora G.Gilli, 2013.

RANCIĖRE, Jacques. Sobre políticas estéticas. Barcelona: Universidad Autónoma de Barcelona, Servei de pubications, 2005 .

O espectador emancipado.São Paulo, SP, Martins Fontes, 2012.

SCHILLER, Friederich. A educação estética do homem em uma série de cartas. São Paulo: Editora Iluminuras, 1989.

STIEGLER, Bernard; MEDEIROS, Maria Beatriz de (org. e trad.). Bernard Stiegler: reflexões (não)contemporâneas.Chapecó: Argo, 2007. 


\section{artigos}

BERENSTEIN, Paola. Elogio aos errantes. Breve histórico das errâncias urbanas. In Revista Vitruvius, ano 05, out. 2004. Disponível em: http://www.vitruvius.com.br/revistas/read/arquitextos/05.053/536

FOUCAULT, Michel. De outros espaços. Conferência proferida no Cercle d'Études Architecturales, em 14 de Março de 1967.

MEDEIROS, Maria Beatriz.Arte,performance e rua. In Revista ArteFilosofia. UFOP, n¹2, junho de 2012. Disponível em: http://www.raf.ifac.ufop.br/pdf/artefilosofia_12/(7)Medeiros.pdf

RANCIĖRE, Jacques. A comunidade estética. Revista Poiésis, n.17, p.169-187, julho de 2011.

A revolução estética e seus resultados. Revista New Left Review, NLR, n.14,p.115-133, março-abril de 2002.

catálogo

A Cidade do Homem Nu.Flávio de Carvalho. Museu de Arte Contemporânea de São Paulo, 2010. 